University of Nebraska - Lincoln

DigitalCommons@University of Nebraska - Lincoln

Papers in the Earth and Atmospheric Sciences

Earth and Atmospheric Sciences, Department

$6-27-2007$

\title{
A 2650-year-long record of environmental change from northern Yellowstone National Park based on a comparison of multiple proxy data
}

\author{
Cathy Whitlock \\ Montana State University,whitlock@unca.edu \\ Walter Dean \\ US Geological Survey, Denver Federal Center, Denver CO \\ Joseph Rosenbaum \\ US Geological Survey, Denver Federal Center, Denver CO \\ Lora Stevens \\ California State University-Long Beach, lora.stevens@csulb.edu \\ Sherilyn C. Fritz \\ University of Nebraska-Lincoln, sfritz2@unl.edu \\ See next page for additional authors \\ Follow this and additional works at: https://digitalcommons.unl.edu/geosciencefacpub \\ Part of the Earth Sciences Commons
}

Whitlock, Cathy; Dean, Walter; Rosenbaum, Joseph; Stevens, Lora; Fritz, Sherilyn C.; Bracht, Brandi; and Power, Mitchell, "A 2650-year-long record of environmental change from northern Yellowstone National Park based on a comparison of multiple proxy data" (2007). Papers in the Earth and Atmospheric Sciences. 2.

https://digitalcommons.unl.edu/geosciencefacpub/2

This Article is brought to you for free and open access by the Earth and Atmospheric Sciences, Department of at DigitalCommons@University of Nebraska - Lincoln. It has been accepted for inclusion in Papers in the Earth and Atmospheric Sciences by an authorized administrator of DigitalCommons@University of Nebraska - Lincoln. 


\section{Authors}

Cathy Whitlock, Walter Dean, Joseph Rosenbaum, Lora Stevens, Sherilyn C. Fritz, Brandi Bracht, and Mitchell Power 


\title{
A 2650-year-long record of environmental change from northern Yellowstone National Park based on a comparison of multiple proxy data ${ }^{\text {t }}$
}

\author{
Cathy Whitlock ${ }^{\mathrm{a}, *}$, Walter Dean ${ }^{\mathrm{b}}$, Joseph Rosenbaum ${ }^{\mathrm{b}}$, Lora Stevens ${ }^{\mathrm{c}}$, Sherilyn Fritz ${ }^{\mathrm{d}}$, \\ Brandi Bracht ${ }^{\mathrm{d}}$, Mitchell Power ${ }^{\mathrm{e}}$ \\ ${ }^{a}$ Department of Earth Sciences, Montana State University, Bozeman MT 59715 \\ ${ }^{\mathrm{b}}$ US Geological Survey, Denver Federal Center, Denver CO 80225 \\ ${ }^{\mathrm{c}}$ Department of Geological Sciences, California State University-Long Beach, Long Beach CA 90840 \\ ${ }^{\mathrm{d}}$ Department of Geosciences, University of Nebraska, Lincoln NE 68588 \\ ${ }^{\mathrm{e}}$ Institute of Geography, School of Geosciences, University of Edinburgh, Edinburgh, EH8 9XP
}

\begin{abstract}
Geochemical, stable-isotope, pollen, charcoal, and diatom records were analyzed at high-resolution in cores obtained from Crevice Lake, a varved-sediment lake in northern Yellowstone National Park. The objective was to reconstruct the ecohydrologic, vegetation, and fire history of the watershed for the last 2650 years to better understand past climate variations at the forest-steppe transition. The data suggest a period of limited bottom-water anoxia, relatively wet winters, and cool springs and summers from 2650 to 2100 calyr BP (700-150 BC). Dry warm conditions occurred between 2100 and 850-800 cal yr BP (150 BC and AD 1100-1150), when the lake was anoxic, winter precipitation was low, and summer stratification was protracted. The data are consistent with overall warmer/drier conditions during the Medieval Climate Anomaly, although they suggest a shift towards wetter winters within that period. The period from 850 to 800 cal yr BP (AD 1100-1150) to 250 cal yr BP (AD 1700) was characterized by greater water-column mixing and cooler spring/summer conditions than before. In addition, fire activity shifted towards infrequent large events and pollen production was low. From 250 to 150 cal yr BP (AD 1700-1800), winter precipitation was moderate compared to previous conditions, and the lake was again stratified, suggesting warm summers. Between 150 and 42 calyr BP (AD 1800-1908), winter precipitation increased and spring and summer conditions became moderate. Metal pollution, probably from regional mining operations, is evident in the 1870s. Large fires occurred between ca. 1800-1880, but in general the forests were more closed than before. The Crevice Lake record suggests that the last 150 years of Yellowstone's environmental history were characterized by intermediate conditions when compared with the previous 2500 years.
\end{abstract}

(C) 2007 Elsevier Ltd and INQUA. All rights reserved.

\section{Introduction}

The northern part of Yellowstone National Park (YNP) is a mixture of steppe and forest within the Lamar River

\footnotetext{
All authors contributed to the overall conceptual design of the analysis and to the final paper. Whitlock and Dean drafted the paper and figures, Whitlock contributed the pollen analysis and interpretation, Dean and Rosenbaum contributed and interpreted the geochemical data, Stevens is responsible for the isotopic analysis and interpretation, Power contributed the fire history, and Fritz and Bracht provided the diatom data and interpretations.

${ }^{*}$ Corresponding author. Tel.: + 4069946910.

E-mail address: whitlock@montana.edu (C. Whitlock).
}

and Yellowstone River watersheds. This region is called the northern range, because it is the historic winter range of Yellowstone's elk and bison herds. Since the 1960s, when the park adopted a management policy of natural regulation, claims have been made that the northern range has been overgrazed and riparian communities have been deteriorating as a result of heavy ungulate winter use. In 1998, the US Congress directed the National Park Service (NPS) "to initiate a National Academy of Sciences review of all available science related to the management of ungulates and the ecological effects of ungulates on the range land of YNP and to provide recommendations for implementation by the Service". The final report of this 
review was published in 2002 by an interdisciplinary panel of scientists (National Research Council, Committee on Ungulate Management in Yellowstone National Park, 2002). Among the findings was that northern YNP lacked sufficient paleoecological data to document the range of historical environmental variability and identify particular ecological attributes that might signal unacceptable conditions. A recommendation was that more research was needed to fully assess natural variation and to better link past and present processes in the region.

This mandate motivated the study of sediment cores from Crevice Lake (lat. $45.000 \mathrm{~N}$, long. $110.578 \mathrm{~W}$, elev. $1713 \mathrm{~m}$ ), a closed basin at the lower forest/steppe border in the canyon of the Yellowstone River in northern YNP (Fig. 1). Its limited surface area $(7.76 \mathrm{ha})$, conical bathymetry, and deep water $(>31 \mathrm{~m})$ create anoxic conditions that preserve annually laminated sediments (varves). The Crevice Lake drainage basin currently supports open forests of Pseudotsuga menziesii, Juniperus scopulorum, and Pinus flexilis, as well as steppe dominated by Artemisia tridentata and bunchgrasses. At higher elevations, Pinus contorta, Abies lasiocarpa, and Picea engelmannii become abundant. A rocky scree slope is present along the northern side of the watershed, but most of the catchment is vegetated. Betula occidentalis, Alnus incana, and Salix spp. grow in moist settings, and Carex, Scirpus, and Typha latifolia are present along the lake margin.

To gain an understanding of the climatic and ecohydrologic history of the northern range, we examined the

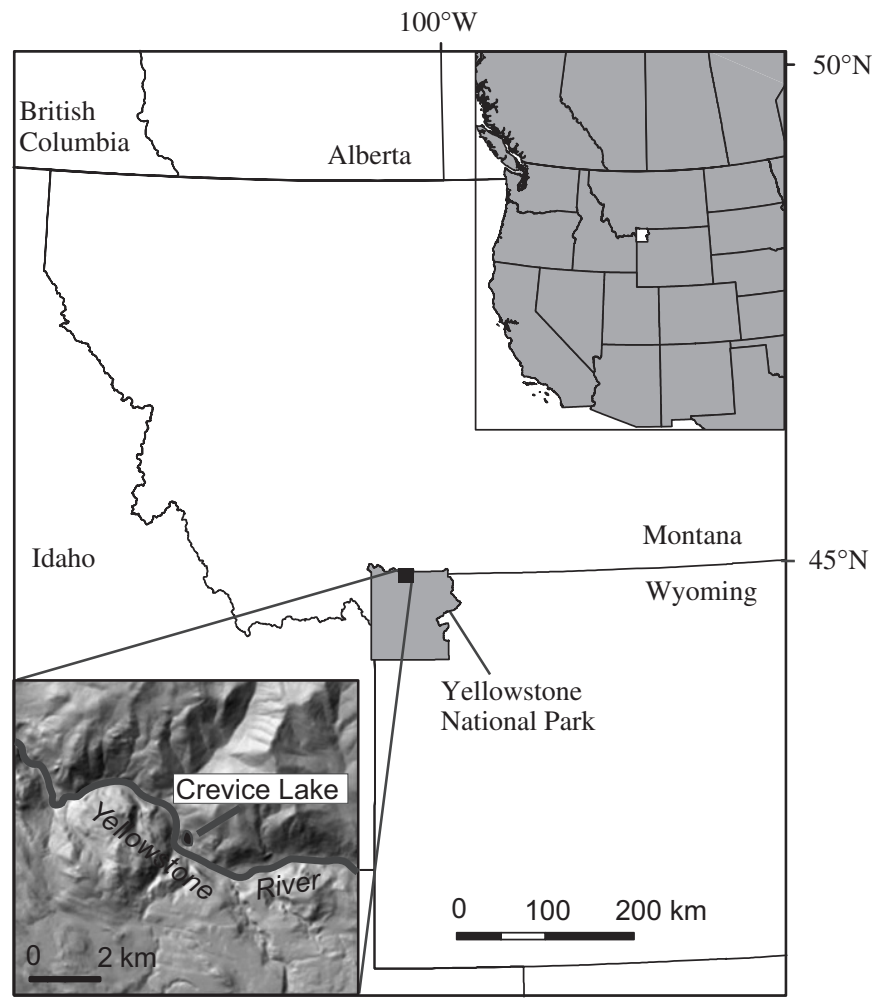

Fig. 1. Location of Crevice Lake and Yellowstone National Park. last 2650 years of the Crevice Lake record. Sediment cores were collected from the ice surface in February 2001 with Livingstone and UWITEC percussion coring systems, as well as a freeze-box corer. Two overlapping Livingstone cores and four overlapping UWITEC cores were retrieved, split longitudinally, and photographed at $10 \mathrm{~cm}$ intervals. The photographs provide an archive of sample locations and thicknesses, macrofossil locations, and general sedimentary changes. Several distinct marker beds allowed easy correlation of cores. The Livingstone cores were archived and sampling was done on the 8-cm-diameter UWITEC cores and the freeze cores.

Several data sets were examined in this study. Core lithology and elemental geochemistry were analyzed to document erosional inputs, changes in water chemistry, and variations in bottom-water oxygen conditions. Geochemical data helped to identify the major sediment components as detrital rock debris, endogenic $\mathrm{CaCO}_{3}$, organic matter, and biogenic silica (diatom remains). Fossil diatoms provided a proxy of lake stratification, nutrient status, and timing of ice-off. Variations in the abundance of macroscopic charcoal particles indicated past changes in fire activity in the watershed. Fossil pollen data revealed the nature of past vegetation and changes in pollen production related to conditions during the flowering season.

\section{Chronology and sampling strategy}

An age model was constructed from a combination of accelerator mass spectrometer (AMS) radiocarbon dates (Table 1) and varve counts. AMS radiocarbon ages were obtained from six plant macrofossils from the upper $1.1 \mathrm{~m}$ of the UWITEC core, although one was excluded from the age model (see Stevens and Dean, this volume). Samples were prepared in the USGS ${ }^{14} \mathrm{C}$ laboratory in Reston, Virginia, and the dating was done at the Center for Accelerator Mass Spectrometry (CAMS) at Lawrence Livermore National Laboratory in Livermore, California. Radiocarbon ages were calibrated with the CALIB 5.2 program (Stuiver et al., 1998), and calibrated ages are listed in Table 1 as calyr BP (before AD 1950) and plotted as cal yr BP and BC/AD. A third-order polynomial fit to the depth and age data (Fig. 2) provides the best estimate of the age/depth relations.

The UWITEC cores were sliced along bedding planes at 2-4 $\mathrm{mm}$ intervals over the upper $112 \mathrm{~cm}$, and the number of laminations was counted three times to produce a varve chronology. The average sample was $3 \mathrm{~mm}$ thick and represented an average of 7 years, and there was no trend in varve number $\mathrm{cm}^{-1}$ through the length of the record.

Contiguous samples were analyzed for magnetic properties, stable isotopes, carbons, charcoal, and diatoms. The freeze core was analyzed for pollen and isotopes and so those records extend to present day; other analyses focused on the UWITEC core and extend to $42 \mathrm{calyr}$ BP (AD 1908). Major- and trace-element geochemistry was done on 
Table 1

Radiocarbon ages and the calibrated age equivalents used in constructing the Crevice Lake age model

\begin{tabular}{|c|c|c|c|c|c|c|c|}
\hline Sample ID & Lab no. & $\begin{array}{l}\text { Depth below } \\
\text { mud-water } \\
\text { interface }(\mathrm{cm})\end{array}$ & Material & $\begin{array}{l}{ }^{14} \mathrm{C} \text { age } \\
(\mathrm{yr} \mathrm{BP})\end{array}$ & $\begin{array}{l}\text { Age error } \\
\text { (yr) }\end{array}$ & $\begin{array}{l}\text { Calibrated range } 2 \\
\text { sigma (cal yr BP) }\end{array}$ & $\begin{array}{l}\text { Mid point } \\
\text { (cal yr BP) }\end{array}$ \\
\hline CV-25 & WW-4618 & 20.45 & $\begin{array}{l}\text { Pseudotsuga } \\
\text { needle }\end{array}$ & 210 & 55 & $59-320$ & 190 \\
\hline $\begin{array}{l}\text { CV-108/ } \\
109\end{array}$ & WW-4619 & 49.45 & $\begin{array}{l}\text { Pseudotsuga } \\
\text { needle }\end{array}$ & 1010 & 55 & 791-1010 & 900 \\
\hline CV-148 & WW-4625 & 63.3 & $\begin{array}{l}\text { Pseudotsuga } \\
\text { needle }\end{array}$ & 1610 & 120 & $1298-1741$ & 1529 \\
\hline CV-184 & WW-4626 & 75.85 & $\begin{array}{l}\text { Pseudotsuga } \\
\text { needle }\end{array}$ & 1920 & 120 & $1562-2149$ & 1855 \\
\hline $\mathrm{CV}-213^{\mathrm{a}}$ & WW-4620 & 83.85 & bark & 2390 & 45 & $2337-2519$ & 2428 \\
\hline $\mathrm{CV}-272$ & WW-4621 & 104.15 & $\begin{array}{l}\text { Pseudotsuga } \\
\text { needle }\end{array}$ & 2500 & 80 & $2362-2742$ & 2552 \\
\hline
\end{tabular}

${ }^{\text {a }}$ Not used in age-depth model.

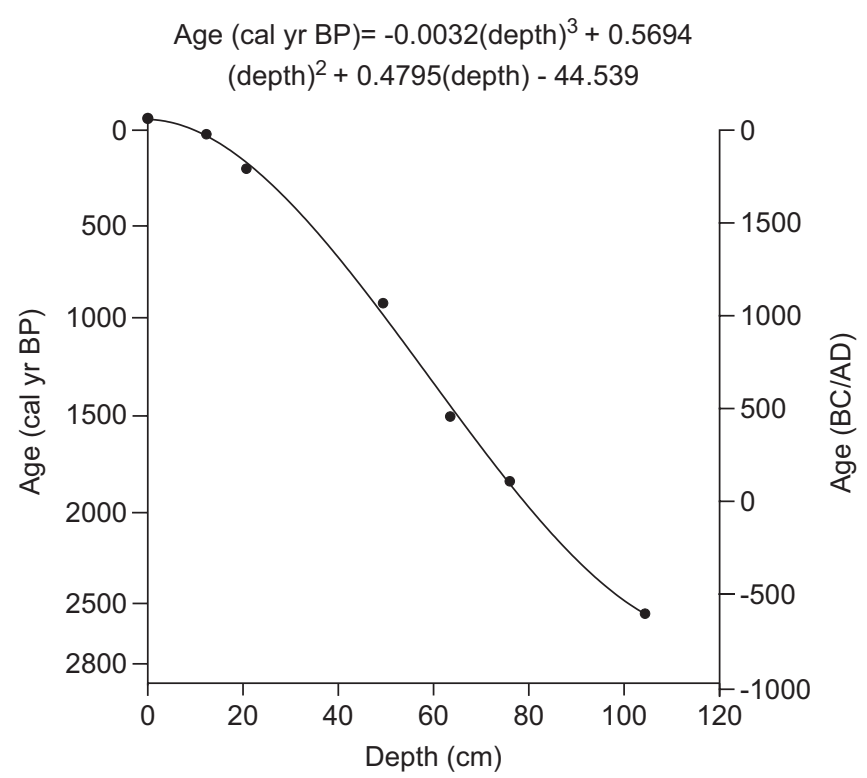

Fig. 2. Age versus depth relations based on calibrated AMS radiocarbon dates (see Table 1 for ages). Cal yr BP indicates years before AD 1950.

every other sample, and XRD was measured on every eighth sample. Pollen samples were spaced $5-7 \mathrm{~cm}$ apart, representing ca. 20-45-yr intervals. This sampling resolution allowed us to look at variability occurring on multidecadal and longer time scales.

\section{Analytical methods}

\subsection{Geochemistry and magnetic susceptibility}

Concentrations of total carbon (TC) and total inorganic carbon (TIC) were determined by coulometric titration of $\mathrm{CO}_{2}$ following extraction from the sediment by combustion at $950{ }^{\circ} \mathrm{C}$ and acid volatilization, respectively (Engleman et al., 1985), in the USGS laboratories, Denver CO. Weight percent TIC was converted to weight percent $\mathrm{CaCO}_{3}$ by dividing TIC by 0.12 , the fraction of carbon in $\mathrm{CaCO}_{3}$. Total organic carbon (TOC) was determined as the difference between TC and TIC. The accuracy and precision for both TC and TIC, determined from hundreds of replicate standards (reagent-grade $\mathrm{CaCO}_{3}$ and a Cretaceous OC-rich marlstone), were usually better than $0.10 \mathrm{wt} \%$. Two standards were run at the beginning of each sample run and one at the end.

Samples were analyzed for 40 major, minor, and trace elements by inductively coupled plasma-mass spectrometry (ICP-MS) by SGS Minerals Services, Toronto, Canada. Rock standards (USGS) were included with the sediment samples, and $5 \%$ of the samples were analyzed in duplicate. The precision, determined by analyzing rock standards and duplicate sediment samples, was better than $10 \%$ and usually better than $5 \%$ at a concentration of 10 times the limit of detection.

For magnetic susceptibility (MS) measurements, samples were placed in nonmagnetic $3.2-\mathrm{cm}^{3}$ plastic boxes. MS values, which were acquired after drying to eliminate the diamagnetic effects of pore water, were measured in a 600$\mathrm{Hz}$ alternating field with amplitude of about $0.1 \mathrm{mT}$. The MS readings were corrected for the diamagnetic effect of sample boxes.

\subsection{Stable isotopes}

Stable isotopic measurements were undertaken on bulk sediment that had been pretreated and sieved to remove organic matter and shells (see Stevens and Dean, this volume). Isotopic measurements were made on a Finnigan MAT 252 mass-spectrometer coupled to a Kiel II carbonate sampling device at the University of Minnesota, Minneapolis. Results are reported in the usual per mil (\%) $\delta$ - notation relative to the Vienna Pee Dee Belemnite (VPDB) marine-carbonate standard for carbon and oxygen:

$\delta \%=\left[\left(R_{\text {sample }} / R_{\mathrm{VPDB}}\right)-1\right] \times 10^{3}$, 
where $R$ is the ratio $\left({ }^{13} \mathrm{C}:{ }^{12} \mathrm{C}\right)$ or $\left({ }^{18} \mathrm{O}:{ }^{16} \mathrm{O}\right)$. Reproducibility for both oxygen and carbon was $0.06 \%$.

\subsection{Diatoms}

Samples for diatom analysis were treated with cold $10 \%$ hydrochloric acid and hydrogen peroxide to remove carbonates and organic matter, respectively (see Bracht et al., this volume). Samples were rinsed, dried onto coverslips, and the coverslips mounted on slides with Zrax, a permanent mounting medium. At least 300 individuals were identified and counted in each sample. Diatom counts are expressed as percentages relative to the total number of individuals counted in each sample.

\subsection{Pollen}

Fifty-nine pollen samples were prepared using standard procedures (Faegri et al., 1989), and Lycopodium spores were added to enable calculation of pollen concentration. About 300-500 terrestrial pollen grains were counted for each level, and pollen percentages were based on the sum of terrestrial pollen and spores. Diploxylon-type Pinus pollen is referred to Pinus contorta, and haploxylon-type Pinus is attributed to P. flexilis, which grows locally, but $P$. albicaulis from higher elevations in YNP may also have been a minor pollen source. Total Pinus is the sum of the diploxylon-type, haploxylon-type, and pine pollen that could not be differentiated.

The arboreal/nonarboreal ratio is derived from the percentage of tree pollen divided by that of shrubs and herbs. It is used as a proxy of forest cover relative to steppe cover (Whitlock, 1993). Pollen concentration was divided by the deposition time (number of years/ sample) to calculate pollen accumulation rates (PAR, grains $\mathrm{cm}^{-2} \mathrm{yr}^{-1}$ ). Because the usual uncertainties of deposition time were mitigated by varve counts, changes in PAR through time were considered a reasonable record of pollen production in the watershed (see Faegri et al., 1989 for interpretation of PAR).

\subsection{Charcoal}

Macroscopic sedimentary charcoal was sampled from the freeze core $(\sim 1 \mathrm{~mm}$ intervals averaging 0.97 years $)$ and long core $(\sim 3-5 \mathrm{~mm}$ intervals). Samples for charcoal were disaggregated in hot $5 \% \mathrm{KOH}$ for $10-20 \mathrm{~min}$ and gently washed through a $125-\mu \mathrm{m}$-mesh screen. Charcoal particles ( $>125 \mu \mathrm{m}$ in minimum diameter) were tallied at $36 \mathrm{X}$ on a dissecting microscope. Charcoal counts were converted into charcoal concentration (particles $\mathrm{cm}^{-3}$ ) and the data were binned into 10-year intervals. Charcoal accumulation rates (CHAR, charcoal particles $\mathrm{cm}^{-2} \mathrm{yr}^{-1}$ ) were created by interpolating charcoal concentrations by multiplying the average charcoal concentration for each bin by the interpolated sedimentation rate for the period of time represented by each bin.
A decomposition technique, described in Long et al. (1998), was used to separate the CHAR data into two components, background and peaks. The background component likely reflects long-term changes in biomass or the occurrence of regional fires. The peaks component, or large positive deviations of CHAR above the background component, likely reflects fire episodes in the catchment of the lake during the time span of the sample, 1.3 years for the freeze core and 5 years for the long core. The background component was determined using a locally weighted moving average of 150 years. Fire episodes or "peaks" were identified when CHAR exceeded the background CHAR by a prescribed threshold ratio of 1.10 . The threshold ratio was selected based on comparison of CHAR peaks with known fire dates from tree-ring studies in the watershed (Littell, 2002). The number of charcoal peaks $/ 1000 \mathrm{yr}$, referred to as the fire-episode frequency, was calculated by smoothing the binary fire-episode series with a 1000-year moving window width to graphically display variations in the frequency of fire episodes.

\section{Results and discussion}

\subsection{Physical limnology}

The sediment consisted of four-components: (1) detrital rock debris (inferred from $\mathrm{Al}$ and $\mathrm{Ti}$ in Fig. 3(A), for example); (2) endogenic $\mathrm{CaCO}_{3}$ as calcite (Fig. 3C); (3) organic matter (Fig. 3F); and (4) biogenic silica (diatom remains) (not shown).

A record of detrital influx into the lake is provided by elemental chemistry (Fig. 3). Aluminum (Al) and Titanium (Ti) are good measures of detrital input because their concentrations are not affected by weathering and postdepositional alteration. With the exception of several spikes, $\mathrm{Al}$ and $\mathrm{Ti}$ contents varied by a factor of less than 2 , and averaged about $1.5 \%$ and $0.072 \%$, respectively. Assuming that the rock debris in Crevice Lake sediments has the elemental composition of average continental crust $(7.8 \% \mathrm{Al}$ and $0.42 \% \mathrm{Ti})$, the sediment in Crevice Lake contains about $18 \%$ detrital rock debris on average.

The remaining components were primarily endogenic and exhibited large variations in relative amounts (Fig. 3). TOC, which we assumed is the result of primary production in the lake, averaged about $10 \%$. Organic matter, which typically is about twice TOC (Dean, 1999), was therefore about $20 \%$ on average. Seasonal organic productivity probably triggered seasonal precipitation of $\mathrm{CaCO}_{3}$ through the photosynthetic uptake of $\mathrm{CO}_{2}$ and the resultant change of surface-water $\mathrm{pH}$. The $\mathrm{CaCO}_{3}$ content varied considerably with a long-term average of about $10 \%$. The sum of the rough approximations for average rock debris, $\mathrm{CaCO}_{3}$, and organic matter was $48 \%$, which left over $50 \%$ for biogenic Si. Thus, the average sediment would be classified as an organic-rich calcareous diatomite.

Some elements, such as molybdenum (Mo, Fig. 3H), uranium (U, Fig. 3I), vanadium (V, not shown), and nickel 


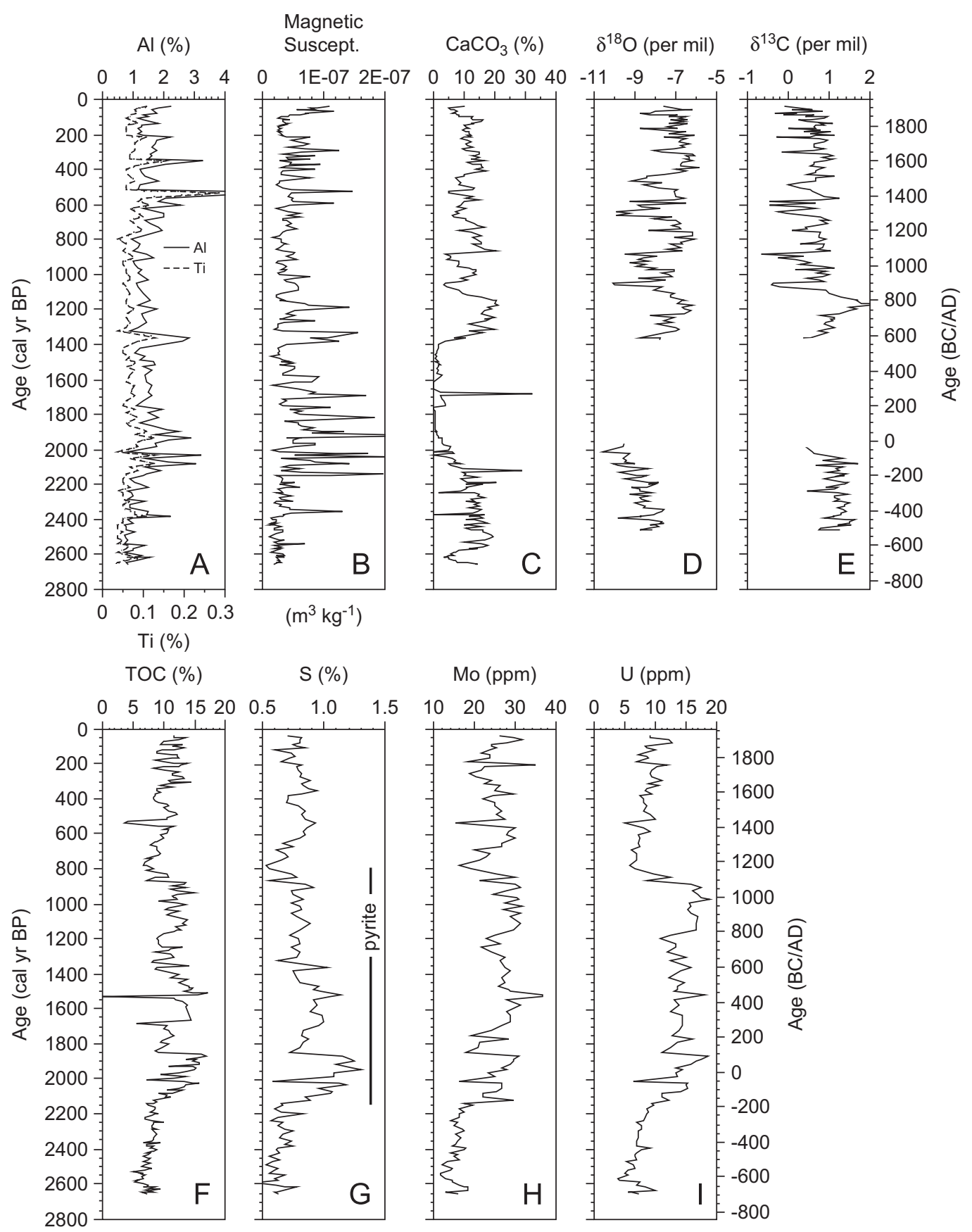

Fig. 3. Profiles of (A) aluminum (Al) and titanium (Ti), (B) magnetic susceptibility, (C) percent $\mathrm{CaCO}_{3}$, (D) $\delta^{18} \mathrm{O}$, (E) $\delta^{13} \mathrm{C}$, (F) total organic carbon (TOC), (G) total sulfur (S), (H) molybdenum (Mo), and (I) uranium (U) versus age in samples from a core from Crevice Lake, Yellowstone National Park.

(Ni, not shown), are concentrated under oxygen-deficient conditions in organic-rich sediments where sulfate reduction occurs (e.g., Piper and Dean, 2002). The concentrations of $\mathrm{U}$ and $\mathrm{Mo}$ in the Crevice Lake sediments were positively correlated among themselves and with TOC and sulfur (S) (Fig. 3F and G). Variations in the concentrations of these elements probably reflect changing redox conditions, with higher concentrations reflecting oxygen-deficient conditions (anoxia in the extreme).

Although MS has commonly been used to interpret variations in detrital material in lake sediments, such an interpretation assumes that detrital Fe-oxide minerals are preserved and that authigenic magnetic minerals (e.g., greigite) have not formed. Relatively poor correlation $\left(R^{2}=0.45\right)$ between $\mathrm{MS}$ and $\mathrm{Al}$ concentration indicated that this was not the case for Crevice Lake. The preservation, destruction, and formation of magnetic minerals apparently were highly sensitive to redox conditions and to the availability of sulfate; however, variations in magnetic susceptibility did not correspond with other indicators of redox conditions (e.g., sulfur content and TOC) (Fig. 3G and F). We suspect that variations in 
susceptibility reflect complex mixtures of magnetic minerals, both remnants of detrital $\mathrm{Fe}$-oxides and possibly variable amounts of authigenic greigite.

Elemental and carbon chemistry data suggest the following sequence of environmental conditions: Prior to 2100 cal yr BP, low concentrations of $\mathrm{S}, \mathrm{Mo}$, and $\mathrm{U}$ indicate that the bottom waters of the lake were oxygen deficient but probably not anoxic. Organic productivity in the epilimnion was substantial but lower than at present ( $<9 \%$ TOC; Fig. 3(F); average of about $14 \%$ organic matter). The influx of allogenic inorganic detritus was relatively low (about $13 \%$ based on $1 \% \mathrm{Al}$; Fig. 3A). $\mathrm{CaCO}_{3}$ content accounted for about $15 \%$ of the total sediment (Fig. 3C), leaving about $60 \%$ that must be biogenic silica.

Between 2100 and 800 calyr BP (150 BC-AD 1150), productivity was high with greater burial of organic matter (about 12\% TOC; Fig. 3F). Bottom waters became more oxygen deficient and probably anoxic throughout the year, resulting in enhanced sulfate reduction in the water column as well as in the sediments and the accumulation of higher concentrations of S (as pyrite), Mo, and U (Fig. 3G-I). Pyrite was detected by XRD in sediments deposited from 2100 to 800 cal yr BP (150 BC-AD 1150), with highest concentrations in sediments deposited between 2100 and 1850 cal yr BP (150 BC-AD 100). These corrosive anoxic bottom waters probably dissolved $\mathrm{CaCO}_{3}$ produced in the surface waters, resulting in very low $\mathrm{CaCO}_{3}$ content between 2100 and 1350 cal yr BP $(150$ BC-AD 600) (although a notable high value of $\mathrm{CaCO}_{3}$ occurred at 1685 cal yr BP [AD 265]) (Fig. 3C). This carbonate-poor, organic-rich sediment was almost black. Also, the amount of detrital clastic material nearly doubled (ca. $26 \%$ based on $2 \% \mathrm{Al}$; Fig. $3 \mathrm{~A}$ ).

At about 1800 cal yr BP (AD 100), TOC, S, and tracemetal concentrations decreased (Fig. 3F and $\mathrm{G}$ ), suggesting higher bottom-water oxygen levels and reduced sulfate (lower S, Mo, and U; Fig. 3-I) The amount of detrital clastic material decreased at this time as indicated by a decline in $\mathrm{Al}$ to about $1.5 \%$ where it remained until about 800 cal yr BP (one exception is a high level of Al at 1357-1377 cal yr BP) (Fig. 3A).

According to the "carbon pump" model of Dean (1999), accumulation of organic matter and $\mathrm{CaCO}_{3}$ in lake sediments is a delicate balance between production rates in the epilimnion and rates of organic-matter decomposition and $\mathrm{CaCO}_{3}$ dissolution in the anoxic, low $\mathrm{pH}$ hypolimnion and sediments. In general, periods of low $\mathrm{CaCO}_{3}$ content at Crevice Lake were associated with high levels of TOC, $\mathrm{S}$, and trace metals indicating low redox conditions and $\mathrm{CaCO}_{3}$ dissolution. However, an increase in $\mathrm{CaCO}_{3}$ content to $>15 \%$ between 1350 and $1100 \mathrm{cal} \mathrm{yr} \mathrm{BP}$ (AD 600-850) occurred when moderate concentrations of TOC, $\mathrm{S}$, and trace metals indicate that bottom waters were still oxygen deficient. This period may have been one of high production of $\mathrm{CaCO}_{3}$ in the epilimnion that overwhelmed dissolution in the hypolimnion.
A major shift in the overall environmental state of the lake occurred between 850 and $800 \mathrm{calyr}$ BP (AD 1100-1150). At $850 \mathrm{calyr}$ BP (AD 1100), concentrations of TOC, $\mathrm{S}$, and trace metals decreased, suggesting increased oxygen in the bottom waters. By $800 \mathrm{cal}$ yr BP (AD 1150), the detrital component (average $\mathrm{Al}=1.8 \%$; Fig. 3A) and organic content (average $\mathrm{TOC}=10 \%$; Fig. 3F) decreased, and carbonate content increased (average $\mathrm{CaCO}_{3}=11 \%$, range 5-20\%; Fig. 3C).

Concentrations of copper $(\mathrm{Cu})$, lead $(\mathrm{Pb})$, arsenic (As), cadmium $(\mathrm{Cd})$, and tellurium $(\mathrm{Te})$ were also measured (Fig. 4). An increase in As levels (Fig. 4C) from 2150 to 1850 cal yr BP (200 BC-100 AD) (probably co-precipitated with pyrite; G. Breit, USGS, personal communication) was generally coincident with the interval when other geochemical indicators indicate that bottom waters were annually anoxic and sulfidic. There were also brief periods in the last 2000 years when concentrations of $\mathrm{Cu}, \mathrm{Pb}$, and $\mathrm{Cd}$ in the sediments peaked. We have no easy explanation for these mostly one-sample peaks.

The metal concentrations in Crevice Lake sediments also define the timing of recent air pollution over YNP (Fig. 4). Concentrations of a number of metals commonly associated with ore deposits increased abruptly near the top of the sediment section. The age of the onset of the anthropogenic increase in metals is very close to the beginning of large-scale mining in Utah, Montana, and Idaho in the 1870s. Although the origin of the metals has not been confirmed, the timing of increased metal concentrations suggests that smelters may have thrown material into the atmosphere and winds carried the material to the Crevice Lake area.

\subsection{Hydrologic variations}

The $\delta^{18} \mathrm{O}$ variations (Fig. 3D) are interpreted as a record of hydrologic variability, in which composition of endogenic carbonates is largely influenced by the isotopic composition of the Yellowstone River (Stevens and Dean, this volume). Crevice Lake lies in the canyon of the Yellowstone River and maintains a groundwater connection with it. Close correspondence between the $\delta^{18} \mathrm{O}$ values at Crevice Lake and the tree-ring inferred discharge of the Yellowstone River (Graumlich et al., 2003) suggests that $\delta^{18} \mathrm{O}$ variations are a response to changes in the amount of spring snowmelt that affects the isotopic composition of the river. In turn, spring snowmelt is a function of winter precipitation at high elevations in YNP. In this model, low (more negative) $\delta^{18} \mathrm{O}$ values correspond with wetter conditions in general, wetter winters in particular, and possibly periods of low summer evaporation. High (less negative) values probably occurred during periods of low snowpack leading to reduced spring discharge, and/or greater summer evaporation. Negative (wetter) deviations are of shorter duration than positive deviations from the long-term average $\delta^{18} \mathrm{O}$ value, suggesting that the lake responds rapidly to wet years. Drought may be poorly 
registered in Crevice Lake relative to lakes in the Northern Great Plains (e.g., Fritz et al., 2000; Laird et al., 2003), which are greatly affected by evaporation, because water residence time is short due to flushing by the Yellowstone River.

The $\mathrm{CaCO}_{3}$ content of the sediments was sufficient for isotopic determinations in the periods from 2650 to 1950 cal yr BP (700 BC-AD 0) and 1380 to 42 cal yr BP
(AD 570-1908). The interval from 2650 to $2000 \mathrm{cal} \mathrm{yr} \mathrm{BP}$ (700-50 BC) exhibited a trend of decreasing $\delta^{18} \mathrm{O}$ values, which suggests a steady increase in spring discharge (and winter precipitation). Variations in $\delta^{18} \mathrm{O}$ values at multi-centennial frequency occurred in last $1350 \mathrm{cal} \mathrm{yr}$ in association with fluctuations in $\mathrm{CaCO}_{3}$ content, with high values from 1350 to 1100 cal yr BP (AD 600-850), 850 to 700 cal yr BP (AD 1100-1250), 600 to 500 cal yr BP
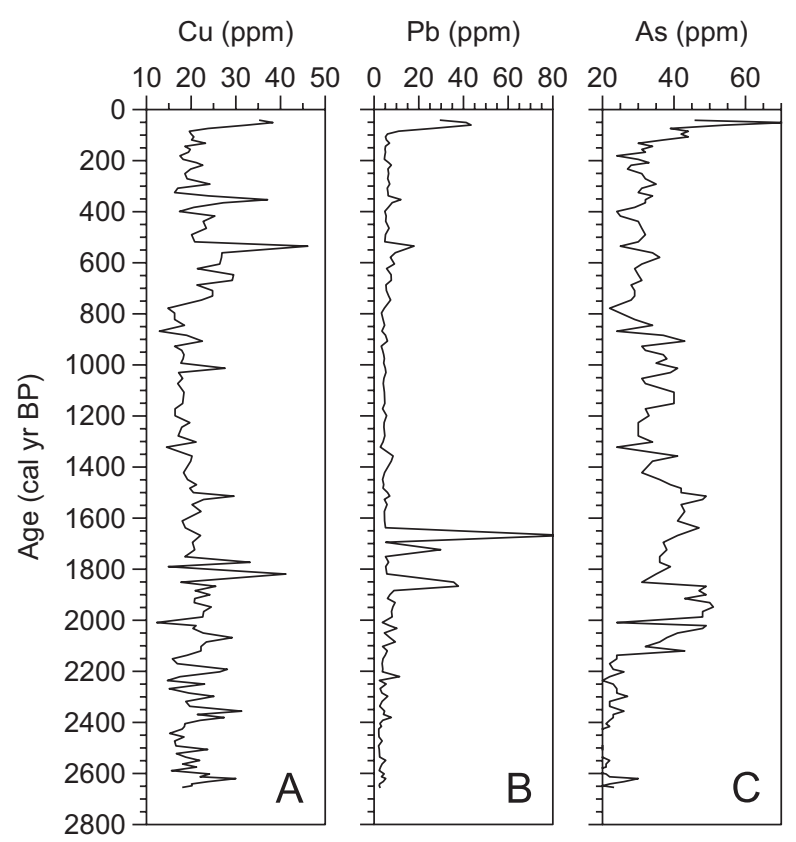

$\mathrm{Cd}(\mathrm{ppm})$

$\mathrm{Te}(\mathrm{ppm})$
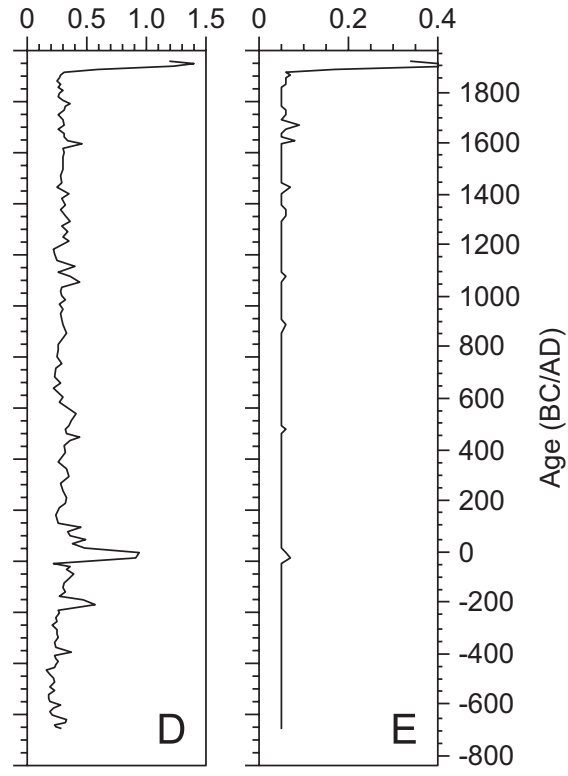

Fig. 4. Profiles of $(\mathrm{A})$ copper $(\mathrm{Cu})$, $(\mathrm{B})$ lead $(\mathrm{Pb}),(\mathrm{C})$ arsenic $(\mathrm{As}),(\mathrm{D})$ cadmium $(\mathrm{Cd})$, and $(\mathrm{E})$ tellurium $(\mathrm{Te})$ versus age in samples from a core from Crevice Lake, Yellowstone National Park.
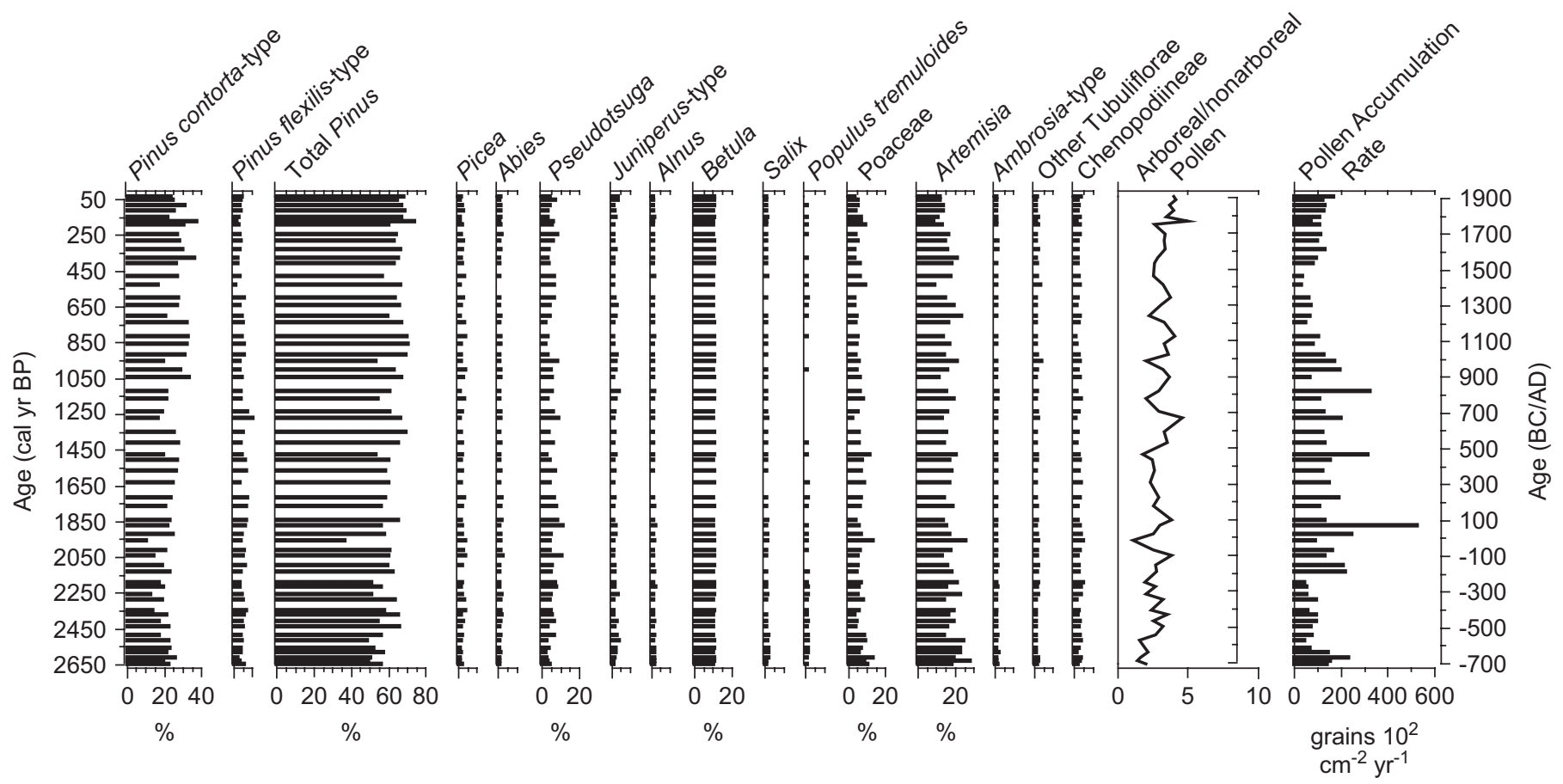

Fig. 5. Pollen record of last 2650 years at Crevice Lake, showing selected taxa, arboreal/nonarboreal pollen ratios, and pollen accumulation rates. 
(AD 1350-1450), and 425 to 42 cal yr BP (AD 1525-1908). Minima of $\delta^{18} \mathrm{O}$ occurred at 450,650, 900, 1050, and 2000 cal yr BP (Fig. 3D), in association with low percentages of $\mathrm{CaCO}_{3}$, and imply that winter precipitation was higher then. These minima were not in association with increases in $\mathrm{S}$, Mo, and $\mathrm{U}$ that would indicate oxygen deficiency, which supports the interpretation that the isotopic record is determined by hydrological (i.e., snowmelt) more than limnological (i.e., evaporative) conditions. The correlation of low $\delta^{18} \mathrm{O}$ values and low percentages of $\mathrm{CaCO}_{3}$ may have been caused by a reduction in carbonate production during times of high snowmelt and lake flushing rather than by greater dissolution due to anoxia.

The carbon-isotope record from Crevice Lake is relatively invariant compared with the large shifts in the oxygen-isotopic record (Fig. 3E). Although small decreases in $\delta^{13} \mathrm{C}$ values occurred during $\delta^{18} \mathrm{O}$ minima (at $450,650,900,1050$, and 2000 cal yr BP), large shifts were not associated with changes in diatom assemblages or indicators of anoxia.

\subsection{Terrestrial ecology}

The pollen record shows only minor stratigraphic variations, implying that the overall distribution of forest and steppe has changed little in the last 2650 years (Fig. 5). Pollen percentages were dominated by Pinus (up to 69\%), mostly diploxylon $P$. contorta-type, which is the dominant conifer of middle and high elevations, especially on rhyolite substrates and areas of recent fire. The steady presence of P. flexilis-type pollen (up to $10 \%$ ) is attributed to locally growing limber pine. Pinus percentages increased slightly in the last 1000 years. Picea and Abies $(<4 \%$ each) are ascribed to long-distance transport from more mesic settings at middle and high elevations. Pseudotsuga and Juniperus-type (probably from J. scopulorum) had slightly

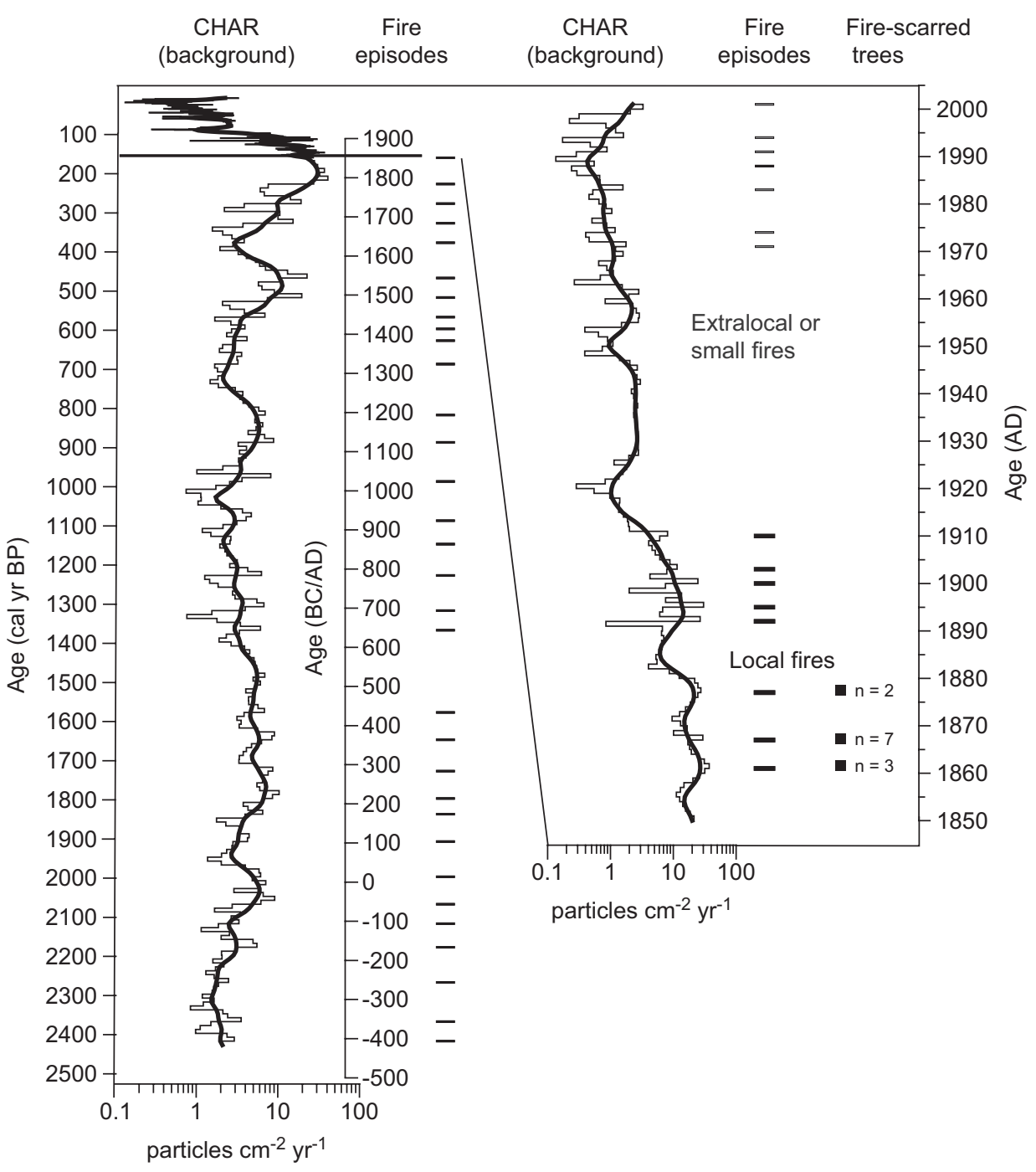

Fig. 6. Charcoal record of last 2400 cal yr BP at Crevice Lake showing charcoal accumulation rates (CHAR), background CHAR (in red), and fire episodes (tic marks). The last 150 years is compared with the number of fire-scarred trees (Littell, 2002) in the Crevice Lake watershed to distinguish local and extralocal or small fires in the charcoal data. 

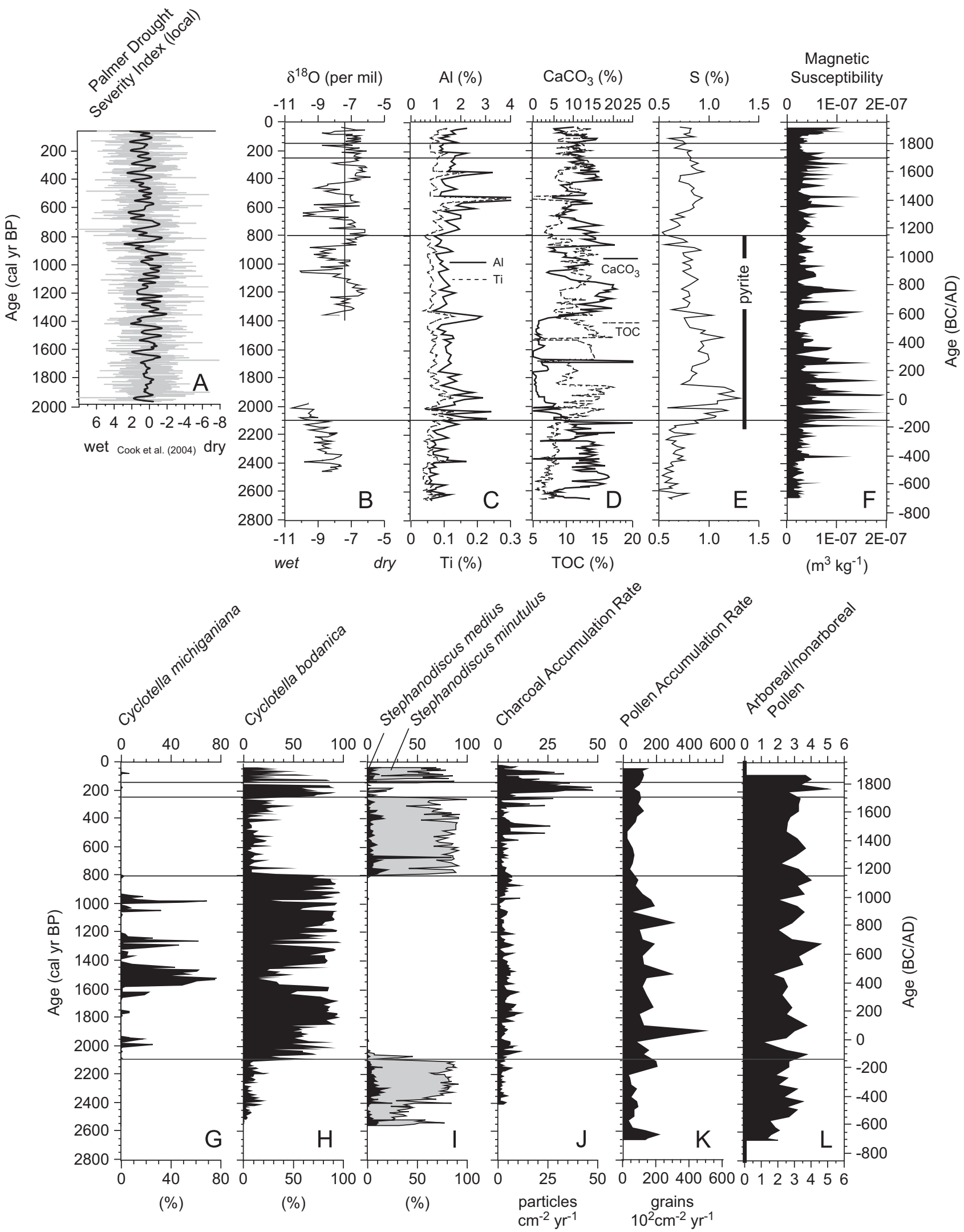

Fig. 7. Profiles of (A) Palmer drought severity index (PDSI), (B) $\delta^{18} \mathrm{O},(\mathrm{C})$ aluminum (Al) titanium (Ti), (D) $\mathrm{CaCO}_{3}$, (E) total sulfur (S), (F) magnetic susceptibility, (G) Cyclotella michiganiana, (H) Cyclotella bodanica, (I) Stephanodiscus medius and S.minutulus, (J) charcoal accumulation rates, (K) pollen accumulation rates, and (L) ratio of arboreal to nonarboreal pollen versus age in samples from a core from Crevice Lake, Yellowstone National Park. Vertical line in $\mathrm{B}$ is the average value of $\delta^{18} \mathrm{O}(-7.35)$ for samples younger than $1400 \mathrm{cal}$ yr BP. Horizontal lines delineate five important periods discussed in text. 
higher values before 1850 cal yr BP (AD 100) $(11 \%$ and $4 \%$, respectively) and after 300 cal yr BP (AD 1650) (7\% and $3 \%$, respectively). Riparian woodland around the lake contributed steady but low amounts of Alnus (probably from A. incana), Betula (from B. occidentalis), and Salix pollen throughout the record (all $<3 \%$ ). Populus tremuloides pollen was present in trace percentages $(<2 \%)$ in the last 2650 years. Poaceae was well represented (up to $12 \%$ ), with slightly decreasing values towards the top of the record. Artemisia, the second most abundant pollen taxa, featured slightly higher percentages in the period before 2000 cal yr BP (150 BC) (up to $27 \%$ ), and values were lower in the last 500 years $(<20 \%)$. Ambrosia-type, other Tubuliflorae, and Chenopodiineae showed little change.

The gradual increase in arboreal/nonarboreal pollen ratios toward the top of the record and especially after 250 cal yr BP (AD 1700) suggests that forest cover has increased. The recent rise is supported by photo comparisons from YNP that show an expansion of forest and an increase in tree density in the last century (Meagher and Houston, 1998). PAR shows greater variability than the percentage data, and probably reflect interannual changes in pollen production, which in turn were influenced by spring and summer conditions that affect cone production and flowering success. Most taxa, including Pinus contortatype, Artemisia, Pseudotsuga, and Poaceae, registered highest PAR before 2550 cal yr BP (600 BC), between 2150 and $1850 \mathrm{calyr}$ BP (200 BC-AD 100), and after $350 \mathrm{cal} \mathrm{BP}$ (AD 1600). A drop in PAR at $800 \mathrm{cal} \mathrm{yr} \mathrm{BP}$ (AD 1150) suggests cooler spring conditions and poor pollen production.

The charcoal data provide information on past variations in charcoal production (background CHAR) and fire frequency (charcoal peaks) (Fig. 6). Overall CHAR levels increased between 500 and 150 cal yr BP (AD 1450-1800). The CHAR record shows little relation to fluctuations in $\mathrm{Al}$ and $\mathrm{Ti}$ (Fig. 3A), which suggests that most of the charcoal is from primary fall-out during a fire and not introduced secondarily as a result of slopewash and erosional processes. Trends in background CHAR suggest changes in available fuel biomass associated with either changes in fuel composition (vegetation) or fuel-moisture levels during the fire season. High CHAR thus indicates the occurrence of large or severe fires that led to the production and deposition of charcoal. CHAR levels were low between 2450 and 500 cal yr BP (500 BC-AD 1450), followed by intervals of high CHAR between 500 and $400 \mathrm{cal}$ yr BP (AD 1450-1550). After 300 cal yr BP (AD 1650), CHAR reached the highest values of the record. CHAR values from the freeze core, sampled at $\sim 1$-year intervals from AD 1850 to 2001, significantly declined during the 20th century. The increase in CHAR in recent centuries was also noted in another high-resolution charcoal record from the northern YNP, located east of Crevice Lake (Millspaugh et al., 2004), suggesting a regional increase in fire activity.

Fire scars occurring on two or more trees identified local (watershed) fires in AD 1860s and 1870s (Littell, 2002); these known events were also registered as charcoal peaks. Charcoal peaks registered since AD 1890 did not match any known fires, and we suggest that they were extralocal and/or small events. About 320,900 ha of YNP burned in AD 1988 (http://www.nps.gov/yell/naturescience/fire.htm), and small fires in the Crevice Lake watershed were registered by a charcoal peak. Fire-free intervals averaged 75 years, but two long fire-free intervals were noted between 1570 and 1350 cal yr BP (AD 380-600) and 810 and 670 cal yr BP (AD 1140-1280).

\subsection{Diatom ecology}

The diatom record (described in greater detail by Bracht et al., this volume) was dominated by several planktic diatom species that differ in nutrient requirements and seasonality (Fig. 7). Stephanodiscus minutulus and S. medius (Fig. 7I), which were abundant after $800 \mathrm{cal} \mathrm{yr} \mathrm{BP}$ (AD 1150) and prior to $2100 \mathrm{cal}$ yr BP $(150 \mathrm{BC})$, are characteristic of periods of deep water-column mixing in the spring months (Interlandi et al., 1999), when phosphorus is regenerated from the hypolimnion and available for planktic algae. In contrast, Cyclotella species, including C. bodanica and C. michiganiana (Fig. $7 \mathrm{G}, \mathrm{H}$ ), bloom during summer stratification, when phosphorus is reduced. Thus, alternations between these two groups reflect differences in the length of summer stratification relative to times of spring isothermal mixing. The diatom data suggest that summer warming occurred earlier in the year, or at least that summers were protracted in the interval between 2100 and $800 \mathrm{cal}$ yr BP (150 BC-AD 1150) and 250 and $150 \mathrm{cal}$ yr BP (AD 1700-1800). These earlier dates correspond with the interval of higher concentrations of TOC, $\mathrm{S}$, and trace metals in the sediments and the inference of more-intense seasonal anoxia. They also match periods of high PAR indicating warm spring/summer conditions.

\section{Conclusions}

The paleolimnologic and paleoenvironmental records of the last 2650 years at Crevice Lake disclose climate variations that occurred on multi-decadal to multi-centennial time scales. These low-frequency variations are evidenced by changes in the timing and length of annual stratification, nutrient status of the lake, and strength of seasonal anoxia in the bottom waters, as well as fluctuations in pollen production, forest density, and fire activity (Fig. 7). The proxy data at Crevice Lake and their comparison with Palmer Drought Severity Index (PDSI) reconstructions of the last 2000 years for the region (Cook et al., 2004, Fig. 7A) identify five important periods:

The interval $2650-2100$ cal yr BP $(700-150$ BC) was a period of weakly oxygenated bottom waters at Crevice Lake, based on low sulfur and trace-metal concentrations, high $\mathrm{CaCO}_{3}$ content, and low influx of detrital clastic material. The abundance of $S$. minutulus relative to $C$. bodanica in the diatom record suggests that the length of 
the summer stratified period was relatively short. The $\delta^{18} \mathrm{O}$ data show a decreasing trend, providing evidence of increasing winter precipitation during this period. PAR and CHAR levels were generally low, implying poor flowering and short fire seasons.

The interval $2100-800$ cal yr BP (150 BC-AD 1150) was a period of year-round anoxia and sulfate reduction that resulted in minimal $\mathrm{CaCO}_{3}$ deposition from 2000 to 1350 cal yr BP (50 BC-AD 600). We assume that yearround anoxia was driven by long or intense summer stratification, indicated by the dominance of $C$. bodanica in the diatom flora. Values of $\delta^{18} \mathrm{O}$ suggest dry winter conditions between 1350 and 1100 cal yr BP (AD 600-850), and wetter conditions between 1100 and 850 cal yr BP (AD 850-1100). PAR values were high during this interval, implying long flowering seasons with abundant cone production, and low CHAR values suggest that fires were small or of low-severity as a result of wet conditions.

This interval includes the so-called Medieval Climate Anomaly (MCA), which has been variously dated between ca. 1300 and 650 cal yr BP (AD 650-1300) in the western US and Great Plains (e.g., Case and MacDonald, 2003; Fritz et al., 2000; Laird et al., 1996; Pierce et al., 2004; Stevens et al., 2006; Woodhouse and Overpeck, 1998). The local PDSI data show persistent dry conditions between 1200 and 900 cal yr BP (AD 750-1050), followed by an interval of alternating wet and dry extremes from 900 to 600 cal yr BP (AD 1050-1350). A tree-ring reconstruction from the Yellowstone area suggests a period of pronounced drought in the early 13th century, followed by periods of moderate drought to the present day (Gray et al., 2007). The Crevice Lake data suggest a warm interval with dry winters between 1350 and 1100 cal yr BP (AD 600-850), followed by less dry but still warm conditions between 1100 and $850 \mathrm{cal}$ yr BP (AD 850-1100). Other studies in YNP indicate that trees grew above present-day treeline and fires were more frequent in the Lamar and Soda Butte drainages between 1200 and 800 cal yr BP (AD 750-1150) (Meyer et al., 1995).

In comparison to the preceding interval, geochemical data indicate that the interval between 800 and 250 cal yr BP (AD 1150-1700) featured less oxygen-deficient conditions in the bottom waters of Crevice Lake. $C$. bodanica, the dominant diatom of the previous period, was replaced by Stephanodiscus medius and $S$. minutulus, species indicating that springs became longer or cooler than before. After 500 cal yr BP (AD 1450), increased CHAR suggests more fire activity and perhaps larger events. Decreased PAR suggests cool spring conditions with poor pollen production. This cool period at Crevice Lake coincides with a time of decreased fire-related debris flow activity in northern YNP (Meyer et al., 1995).

Wet events at 900 cal yr BP (AD 1050) and 650 cal yr BP (AD 1300) are inferred from the $\delta^{18} \mathrm{O}$ minima and correspond with wet intervals in the regional PDSI data and local tree-ring reconstruction (Gray et al.,
2007). A pronounced wet event between 500 and 400 cal yr BP (AD 1450-1550) was not registered in the PDSI record and is recorded as a dry interval in the local reconstruction. One explanation for this discrepancy is the fact that the tree-ring reconstructions are an estimate of annual precipitation and summer moisture deficits, whereas the $\delta^{18} \mathrm{O}$ values of the carbonates are linked to winter precipitation and spring runoff. The tree-ring records may be insensitive to winter moisture if summers were exceptionally dry.

A shift at 800 calyr BP (AD 1150) toward cooler conditions in YNP is consistent with other sites that show a "moisture regime" change in the 12th and 13th century (e.g., Case and MacDonald, 2003; Stine, 1994; Woodhouse and Overpeck, 1998). A rise in lake level and more-frequent fires in northwestern Montana have been attributed to intermittent, less persistent drought episodes in the region (Power et al., 2006; Stevens et al., 2006). Cooler conditions also caused renewed glacial activity in the northern Rockies (e.g., Carrara, 1987; Luckman, 2000), although the timing of advances is highly asynchronous across the region.

The interval 250-150 cal yr BP (AD 1700-1800) featured high percentages of $C$. bodanica implying a return to lengthy summer stratification. Large or severe fires are inferred from very high levels of CHAR. Increased forest density is evidenced by high PAR and arboreal/nonarboreal pollen ratios. Warmer-than-present spring/summers were probably responsible for changes in paleolimnology, increases in forest cover, and a shift to large infrequent fires in YNP.

The interval 150-42 cal yr BP (AD 1800-1908) was marked by an increase in winter precipitation (low $\delta^{18} \mathrm{O}$ ) at the end of the 19th century, which is also noted in the tree-ring reconstruction (Gray et al., 2007). Variable spring and summer conditions are suggested by rapid shifts between $C$. bodanica, $S$. medius, and $S$. minutulus. Several fire events recorded by fire-scarred trees (Littell, 2002) and charcoal peaks between ca. AD 1860-1880 contributed to high levels of CHAR. Fire activity and CHAR have decreased since AD 1900 with charcoal peaks recording only extra-local or small fires. Trace-metal pollution from regional mining operations is also evident since AD 1870s.

Three points are worth mentioning from this initial examination of Crevice Lake. First, the physical and biotic data from the Crevice Lake show considerable variability on multi-decadal to multi-centennial time scales, but the resolution of sampling is not adequate to easily identify higher frequency variability (e.g., ENSO or PDO shifts). Interpretation of the record is complicated by the sensitivities of individual proxies to different aspects of the environment and the likelihood that leads and lags occurred in their respective responses. As an example, the pollen data indicate very little change in vegetation over the last 2650 years, even though the charcoal record suggests that there were several fire events and possibly a change in 
fire severity in the last 500 years. The diatom data show remarkably abrupt shifts that suggest rapid reorganization of the aquatic environment related to the duration and intensity of lake stratification, and these changes in stratification and bottom-water conditions are also reflected in redox-sensitive trace elements. The geochemistry data indicate that the broad period of anoxia, when C.bodanica dominated the diatom flora, eliminated carbonates necessary to measure stable isotopes. The $\delta^{18} \mathrm{O}$ data seem to record variations in Yellowstone River discharge and snow accumulation at higher elevations in YNP. The MS is governed by a number of variables that are internal and external to the lake. The differences among proxies stress the need for multiproxy comparisons at other sites and a better understanding of the factors the control individual responses.

A second observation is that a multiple proxy approach helps flesh out the environmental history by providing information on conditions during different seasons. At this site, the $\delta^{18} \mathrm{O}$ record is sensitive to winter precipitation and spring snowmelt, more than summer evaporation, and the $\mathrm{CaCO}_{3}$ reflects the biological productivity of the surface waters as well as the nature of the bottom-water conditions, both of which are strongly influenced by summer temperature. The diatoms disclose the intensity of lake stratification, which relates to spring and summer conditions. The pollen offers phenological information related to spring and summer as well as multicentennial-scale trends in vegetation and climate. The charcoal data are a record of conditions during the summer fire season. This comprehensive picture of year-round conditions would not be possible from any single data set.

Finally, the data indicate that the last 150 years of environmental history since the formation of YNP has not been anomalous within the range of variability of the last 2650 years, and many of the proxy indicators suggest that 19th and 20th century variability at Crevice Lake was moderate compared with earlier extremes. This conclusion is in agreement with the tree-ring-based precipitation reconstruction, which indicates that the extreme wettest and driest events of the last 110 years fall within the range of precipitation conditions occurring during the last 800 years (Gray et al., 2007). With the possible exception of the charcoal record, all of the data show greater variability in the range of ecosystem conditions prior to the establishment of the YNP in 1872. The physical and biotic conditions expressed at Crevice Lake imply a trend in the last century towards dry winters and variable spring and summer conditions, moderate oxygen deficiency, decreased fires, and somewhat higher forest density. Human activities far removed from the site are also registered, namely the increase in metals associated with mining activities beginning in the 1870s. Comparing the environmental history of recent millennia with that occurring on longer time scales as a result of large-scale changes in the climate system is the next step in this investigation.

\section{Acknowledgments}

We gratefully acknowledge the support of John Varley and Tom Olliff (Yellowstone Center for Resources, Yellowstone National Park) in providing funding and continued logistical support. Ken Pierce assisted with geological interpretation. Field and laboratory assistance was provided by the YNP Fire Cache staff, K. Pierce, J. Stone, L. Doner, J. Honke, G. Skipp, and J. Yale (student intern, NASA award GRNASM99G000001). Comments from two anonymous reviews improved the paper. K. Pierce has also helped with the geologic interpretation of the site. Funds from the Earth Surface Dynamics Program of the US Geological Survey, the Canon Foundation, and National Science Foundation (EAR-9906100 to Whitlock; EAR-9905262 to Stevens and Fritz) supported this project.

\section{References}

Bracht, B.B., Stone, J.R., Fritz, S.C., this volume. A diatom record of lateHolocene climate variability in the northern Rocky Mountains. Quaternary International.

Carrara, P.E., 1987. Holocene and latest Pleistocene glacial chronology, Glacier National Park Montana. Canadian Journal of Earth Sciences 24, 387-395.

Case, R.A., MacDonald, G.M., 2003. Tree-ring reconstructions fo streamflow for three Canadian Prairie rivers. Journal of American Water Resources Association 38, 703-716.

Cook, E.R., Woodhouse, C.A., Eakin, C.J., Meko, D.M., Stahle, D.W., 2004. Long-term aridity changes in the western United States. Science 306, 1015-1018.

Dean, W.E., 1999. The carbon cycle and biogeochemical dynamics in lake sediments. Journal of Paleolimnology 21, 375-393.

Engleman, E.E., Jackson, L.L., Norton, D.R., Fischer, A.G., 1985. Determination of carbonate carbon in geological materials by coulometric titration. Chemical Geology 53, 125-128.

Faegri, K., Kaland, P.E., Krzywinski, K., 1989. Textbook of Pollen Analysis, fourth ed. Blackwell, New York

Fritz, S.C., Ito, E., Yu, Z., Laird, K.R., Engstrom, D.R., 2000. Hydrologic variation in the Northern Great Plains during the last two millennia. Quaternary Research 53, 175-184.

Graumlich, L.J., Pisaric, M.F.J., Waggoner, L.A., Littell, J.S., King, J.C., 2003. Upper Yellowstone River flow and teleconnections with Pacific Basin climate variability during the past three centuries. Climatic Change 59, 245-262.

Gray, S.T., Graumlich, L.J., Betancourt, J.L., 2007. Annual precipitation in the Yellowstone National Park region since AD 1173. Quaternary Research 68 (1), 18-27.

Interlandi, S., Kilham, S., Theriot, E., 1999. Responses of phytoplankton to varied resource availability in large lakes of the Greater Yellowstone Ecosystem. Limnology and Oceanography 44, 682-688.

Laird, K.R., Fritz, S.C., Maasch, K.A., Cumming, B.F., 1996. Greater drought intensity and frequency before AD 1200 in the Northern Great Plains, USA. Nature 384, 552-555.

Laird, K.R., Cumming, B.F., Wunsam, S., Rusak, J.A., Oglesby, R.J., Fritz, S.C., 2003. Lake sediments record large-scale shifts in moisture regimes across the northern prairies of North America during the past two millennia. Proceedings of the National Academy of Sciences 100, 2483-2488.

Littell, J.S., 2002. Determinants of fire regime variables in low elevation forests of the northern Greater Yellowstone Ecosystem. Master's Thesis, Montana State University. 
Long, C.J., Whitlock, C., Bartlein, P.J., Millspaugh, S.H., 1998. A 9000-year fire history from the Oregon Coast Range, based on a high-resolution charcoal study. Canadian Journal of Forest Research 28, 774-787.

Luckman, B.H., 2000. The Little Ice Age in the Canadian Rockies. Geomorphology 32, 357-394.

Meagher, M.M., Houston, D.B., 1998. Yellowstone and the Biology of Time: Photographs from Across a Century. University of Oklahoma Press, Norman.

Meyer, G.A., Wells, S.G., Jull, A.J.T., 1995. Fire and alluvial chronology in Yellowstone National Park; climatic and intrinsic controls on Holocene geomorphic processes. Geological Society of America Bulletin 107, 1211-1230.

Millspaugh, S.H., Whitlock, C., Bartlein, P., 2004. Postglacial fire, vegetation, and climate history of the Yellowstone-Lamar and Central Plateau provinces, Yellowstone National Park. In: Wallace, L. (Ed.), After the Fires: The Ecology of Change in Yellowstone National Park. Yale University Press, New Haven, pp. 10-28.

National Research Council, Committee on Ungulate Management in Yellowstone National Park, 2002. Ecological Dynamics on Yellowstone's Northern Range. National Academy Press, Washington.

Pierce, J.L., Meyer, G.A., Jull, A.J.T., 2004. Fire-induced erosion and millennial-scale climate change in northern ponderosa pine forests. Nature 432, 87-90.

Piper, D.Z., Dean, W.E., 2002. Trace-element deposition in the Cariaco Basin under sulfate reducing conditions - a history of the local hydrography and global; climate, $20 \mathrm{ka}$ to the Present. US Geological Survey Professional Paper 1670, 41pp. 〈http://geopubs.wr.usgs.gov/ prof-paper/pp1670/>.

Power, M.J., Whitlock, C., Bartlein, P.J., Stevens, L.R., 2006. Fire and vegetation history during the last 3800 years in northwestern Montana. Geomorphology 75, 420-436.

Stevens, L.R., Dean, W.E., this volume. Geochemical evidence for hydroclimatic variability over the last 2500 years from Crevice Lake in Yellowstone National Park, USA.

Stevens, L.R., Stone, J.R., Campbell, J., Fritz, S.C., 2006. A 2200 record of hydrologic variability from Foy Lake, Montana USA, inferred from diatom and geochemical data. Quaternary Research 65, 264-274.

Stine, S., 1994. Extreme and persistent drought in California and Patagonia during mediaeval time. Nature 369, 546-549.

Stuiver, M., Reimer, P.J., Bard, E., Beck, J.W., Burr, G.S., Hughen, K.A., Kromer, B., McCormac, G., Van der Plicht, J., Spurk, M., 1998. INTERCAL89 radiocarbon age calibration, 24,000-0 cal BP. Radiocarbon 40, 1041-1083.

Whitlock, C., 1993. Postglacial vegetation and climate of Grand Teton and southern Yellowstone National parks. Ecological Monographs 63, 173-198.

Woodhouse, C.A., Overpeck, J.T., 1998. 2000 years of drought variability in the central United States. Bulletin of the American Meteorological Society 79, 2693-2714. 